\title{
No Regeneration of the Human Acetabular Labrum After Excision to Bone
}

\author{
Hermes H. Miozzari MD, Marco Celia MD, John M. Clark MD, PhD, \\ Stefan Werlen MD, Florian D. Naal MD, Hubert P. Nötzli MD
}

Published online: 4 November 2014

(C) The Association of Bone and Joint Surgeons( 2014

\begin{abstract}
Background Treatment options for a symptomatic, torn, irreparable, or completely ossified acetabular labrum are limited to either excision and/or reconstruction with grafts. In a previous animal model, regeneration of the acetabular labrum after excision to the bony rim has been shown. In humans, less is known about the potential of regeneration of the labrum. Recent studies seem to confirm labral regrowth, but it is still unclear if wide excision might be a surgical option in cases where repair is not possible.
\end{abstract}

Each author certifies that he or she, or a member of his or her immediate family, has no funding or commercial associations (eg, consultancies, stock ownership, equity interest, patent/licensing arrangements, etc) that might pose a conflict of interest in connection with the submitted article.

All ICMJE Conflict of Interest Forms for authors and Clinical Orthopaedics and Related Research ${ }^{\circledR}$ editors and board members are on file with the publication and can be viewed on request.

Each author certifies that his or her institution approved the human protocol for this investigation, that all investigations were conducted in conformity with ethical principles of research, and that informed consent for participation in the study was obtained.

J. M. Clark: University of WA appointment pending.

H. H. Miozzari ( $\square)$

Division of Orthopaedics and Trauma Surgery, University

Hospitals of Geneva and University of Geneva, Rue Gabrielle-

Perret-Gentil 4, 1211 Geneva, Switzerland

e-mail: hermes.miozzari@hcuge.ch

M. Celia, S. Werlen, H. P. Nötzli

Sonnenhof Orthopaedic Center, Bern, Switzerland

J. M. Clark

Overlake Hospital, Bellevue, WA, USA

F. D. Naal

Department of Orthopaedic Surgery, Schulthess Clinic, Zürich, Switzerland
Questions/purposes The purposes of this study were (1) to determine the extent of acetabular labrum regeneration after excision to the bony rim; and (2) to determine whether this procedure results in higher hip scores.

Methods We reviewed all patients treated with surgical dislocation for symptomatic femoroacetabular impingement by a single surgeon at one institution between 2003 and 2008, of whom 14 underwent wide labral excision (of at least $60^{\circ}$ ) down to bone; we used this approach when there was an absence of reparable tissue. Of these 14, nine were available for voluntary reexamination. The mean age at surgery was $38 \pm 9 \mathrm{SD}$ years and the mean followup was $4 \pm 1$ SD years. All patients consented to a physical examination and an MRI arthrogram, which was evaluated for evidence of new tissue formation by four observers. A modified Harris hip score and the UCLA were recorded.

Results Regrowth of a structure equivalent to normal labrum was not observed on the MRI arthrograms. Six of nine hips had segmental defects, bone formation was found in five, and the capsule was confluent with the new tissue in six. The mean Harris hip score at latest followup was $83 \pm 14$, and the mean UCLA score was $6 \pm 2$.

Conclusions Resection of a nonreparable acetabular labrum down to a bleeding bony surface does not stimulate regrowth of tissue that appears to be capable of normal function by MR arthrography, and patients who underwent this procedure had lower hip scores at midterm than previously reported from the same institution for patients undergoing labral repair or sparse débridement. Based on these results, we believe that future studies should evaluate alternatives to reconstructing the labrum, perhaps using ligamentum teres, because resection seems neither to result in regrowth nor the restoration of consistently high hip scores.

Level of Evidence Level IV, therapeutic study. 


\section{Introduction}

Disruption of the acetabular labrum has been recognized as a cause of hip pain and disability for several decades [2]. Until recently, the surgical treatment of choice was resection of the unstable segment, although excision is eventually followed by an unsatisfactory outcome in onethird of reported cases [13, 50]. Experimental evidence suggests that the normal labrum plays a role in joint force distribution, stability, or lubrication $[15,19,23,24,27,30$, $33,44]$ and that loss of this function will predispose subjects to chondral damage even when underlying deformities are corrected.

First described as recently as 1997 [56], labral repair has been integrated into the treatment of femoroacetabular impingement (FAI) following the belief that the labrum contributes to normal function. Animal and clinical studies suggest that repairs can heal $[6,48]$ and that patients with repairs enjoy better function when compared with those with excision $[21,22,31,36,51]$. In cases in which the labrum cannot be repaired as a result of complete ossification, prior resection, radial discontinuity, or poor tissue quality, techniques for labral reconstruction using an iliotibial band, ligamentum teres, or allograft tissue have been described by experienced surgeons treating younger patients with large labral defects [20, 26, 52, 55].

There is evidence, however, that the labrum may regenerate after surgical excision, thus obviating the need for a difficult repair or reconstruction. Abrams et al. [1] observed "homogeneous regrowth" of the labrum in 21 of 24 patients by arthroscopy 2 years after open excision. In an animal model, we observed that the resected acetabular labrum was replaced by fibrous scar that approximated the original tissue in density, contour, and apposition to the femoral head [43]. Histologically, the regenerated tissue was dense, fibrous, well fixed to the bone, and distinct from the capsule but did not reproduce the normal collagen structure. Specifically, large circumferential fibers were not evident. Neither subluxation nor severe arthrosis was observed at 1 year. The technique included exposure of a bleeding bone bed.

In our clinical practice treating FAI with surgical dislocation, irreparable labral lesions once were managed with resection of the diseased segment and exposure of bleeding bone along the subjacent acetabular rim. If this technique leads to regrowth of fibrous tissue similar to that found in the sheep model, resection might provide an alternative to reconstruction with graft.

We therefore retrospectively reviewed our experience with this approach (1) to evaluate the extent of acetabular labrum regeneration after surgical excision to the bony rim (using MR arthrography [MRA] to evaluate this endpoint); and (2) to determine whether this procedure later has an important correlation with results in higher hip scores.

\section{Patients and Methods}

We reviewed all hips treated using surgical hip dislocation $(n=450)$ for the treatment of FAI performed by the senior author (HPN) between 2004 and 2008 at a single institution and identified 14 patients with an extensive labral excision. During the period in question, the author's general indications for performing an extensive labral excision included a labrum completely ossified or a labrum too fragile or too thin to be refixed. At that time, the author did not perform any labral reconstructions.

After first contact by telephone, all patients willing to participate were sent an informed consent with all the information about the study. Three resided abroad and two declined participation in the study. Thus, nine patients were available for voluntary evaluation at a mean followup of $4 \pm 1$ years (range, 3-7 years) after surgery. After a structured interview and a physical examination for the modified Harris hip score, an MRA of the involved hip was obtained and then discussed with each patient.

A questionnaire with the UCLA activity score [58] was sent 2 to 3 weeks before the voluntary reexamination was completed by all patients.

The average age at surgery was 39 years (range, 2748 years). Three were women (average age, 46 years) and six men (average age, 34 years). Mean body mass index at surgery was $25 \pm 2 \mathrm{~kg} / \mathrm{m}^{2}$. One patient had undergone hip arthroscopic labral débridement 16 months before the surgical hip dislocation.

The presurgical evaluation, surgical indications, procedure, and rehabilitation for treatment of FAI in this timeframe at our institution have been published [45]. The extent of the labral resection was detailed in the operative notes, except in one, in which the description was limited to "anterior." Before the FAI surgery, seven patients were classified as having "cam" impingement secondary to deformity of the femoral head/neck junction, one had a "pincer" deformity resulting from a coxa profunda, and one had a mixed type of impingement.

The study was approved by the local ethical committees (Kantonale Ethikkommission Bern; KEK 188/09) and was carried out in accordance with the World Medical Association Declaration of Helsinki and according to the Guidelines and Recommendations for European Ethics Committees by the European Forum for Good Clinical Practice. All patients gave written informed consent. All surgeries were performed by the senior author.

The approach for surgical dislocation has been published elsewhere [10] as have specific details of our method 
for grading and managing labral lesions [45]. Briefly, all patients were positioned in the lateral recumbent position. We routinely performed a Henry approach that uses the interval between the gluteus medius and maximus without splitting gluteus maximus fibers [45]. Starting in 2006, a Z-shaped, stepped trochanteric flip osteotomy was used instead of the earlier flat osteotomy [8]. A Zshaped capsulotomy and subsequent cutting of the ligamentum teres allowed complete dislocation of the femoral head and full visualization of the hip. When possible a detached labrum was repaired using suture anchors. When a labrum was completely ossified or too fragile or too thin to be refixed as a result of insufficient tissue volume or discontinuity, as was the case in all patients in the present series, the segment was excised. The extent of the excision ranged from 3 to 9 clockface hours but always included the segment from 12:00 to 14:30 (Table 1). Acetabular labrum ossifications were observed in all but one patient. All calcified fibrocartilage beneath the zone of labral resection was removed, exposing bleeding bone on the true acetabular rim. Osteochondroplasty to create an optimized waist at the femoral head-neck junction was performed as indicated in patients with cam or mixed impingement. Sufficient correction, defined as intraoperative impingement-free hip internal rotation of $>30^{\circ}$ and flexion of $>115^{\circ}$, was confirmed by repeated passive motion testing of the relocated hip. Unstable chondral flaps remaining after rim trimming were resected, and, if necessary, microfracturing was performed. Bone wax was not used. The capsule was closed and the osteotomy of the trochanter refixed with two $3.5-\mathrm{mm}$ cortical screws.

Range of motion was restricted initially with gradual resumption of full weightbearing and activity after a first clinical and radiographic evaluation at 6 weeks, confirming healing of the trochanteric osteotomy in all.

\section{Arthro-MRI}

At the time of the voluntary evaluation, MRA of the involved hip was performed with a 3-T unit, and images were processed including 14 radial sections along the axis of the femoral neck in a plane through the femoral head center [18].

A qualitative evaluation of the followup MRA was carried out independently by three orthopaedic surgeons (HHM, HPN, JMC) and one musculoskeletal radiologist (SW) and final interpretation was based on consensus. The condition of the articular cartilage (signal alterations to full-thickness lesions), of the capsule (defects, intraarticular adhesions), and of the acetabular labrum (size and composition) was recorded using a clockface

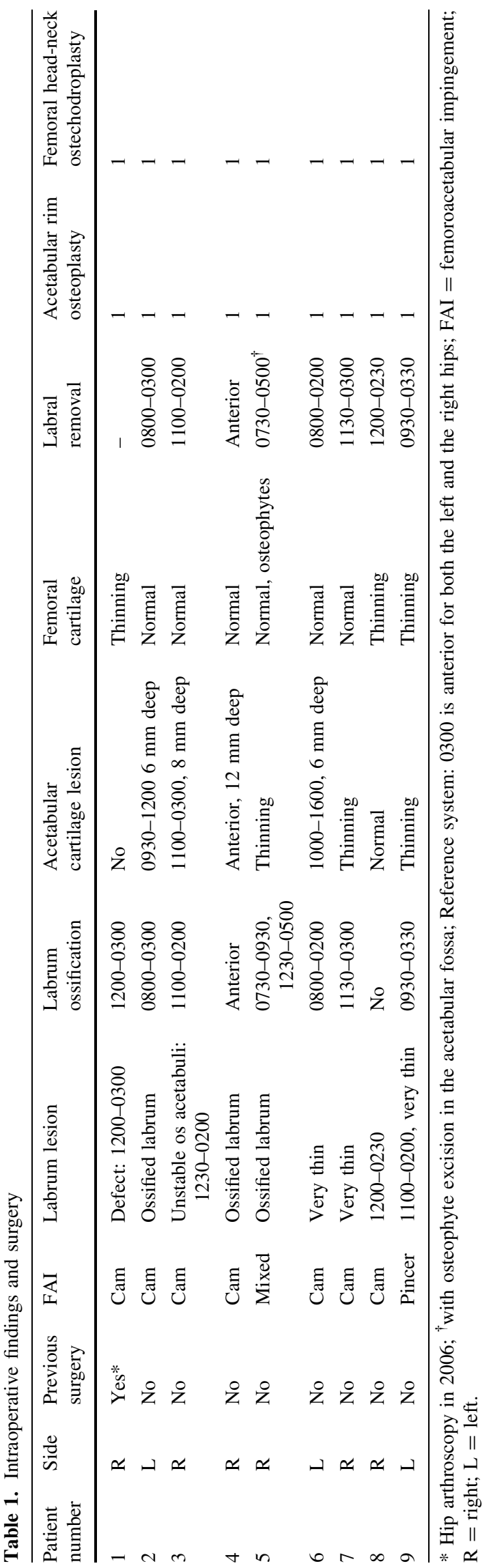



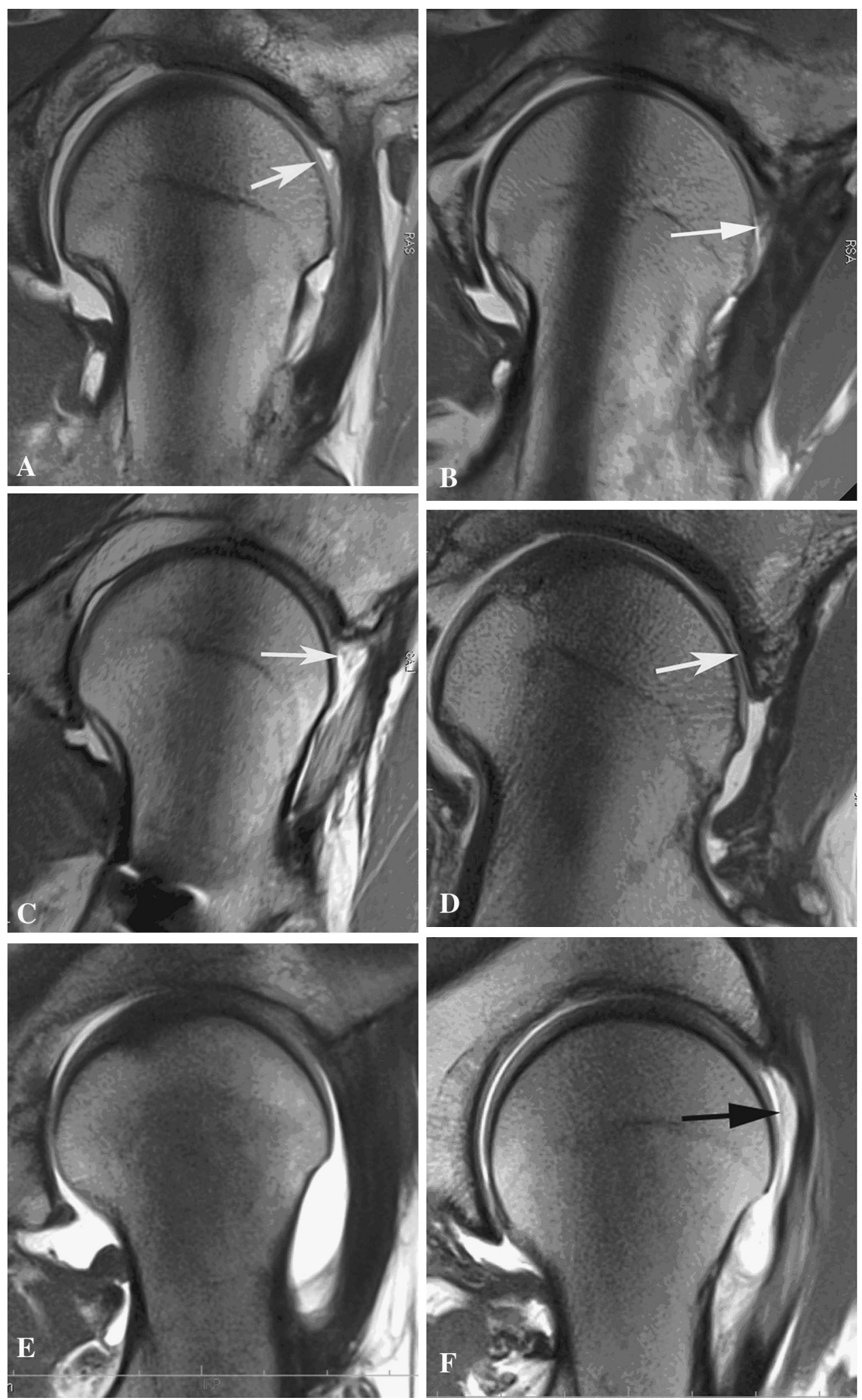

reference system to identify location. The 12 o'clock position was in line with the head of the patients, and 3 o'clock was anterior for both the right and the left hip.
For each section in the radial reconstructions, the MRI appearance of tissue within the zone of resection recorded in the operative note was classified as A, no regeneration (a 
4Fig. 1A-G These are illustrations of the MRA appearance of the tissue response in the area of previous resection of the acetabular labrum down to the bony rim as seen on radial views. In each case, the capsule and adjacent musculature have reconstituted after surgical dislocation and anterior arthrotomy. (A) No regrowth; a void is present between the capsule and the femoral head (white arrow) (response A). (B) Replacement with tissue (white arrow) resembling the normal labrum in density, shape, and location relative to the acetabular rim and femoral head (read as response B1). Infiltration of contrasts shows a probable tear in the new labral tissue. Major adhesions between the neck in the area of femoral osteoplasty are visible. (C) Tissue has formed in the void (white arrow) but is low-density fibrous tissue or synovium (response B2). (D) The void has been filled with bone (response B3). Where the undersurface of the bone abuts the femoral head, it is smooth and covered with soft tissue (white arrow), similar to an osteophyte. (E) The resection site is filled with dense fibrous tissue indistinguishable from the adjacent capsule and similar in density to normal labrum (response C1). (F) The void has been partially replaced with lowdensity tissue (black arrow) that is fused with the capsule (response C2). (G) The area of prior resection is largely replaced by bone (white arrow) that is enveloped by the capsule (response C3).

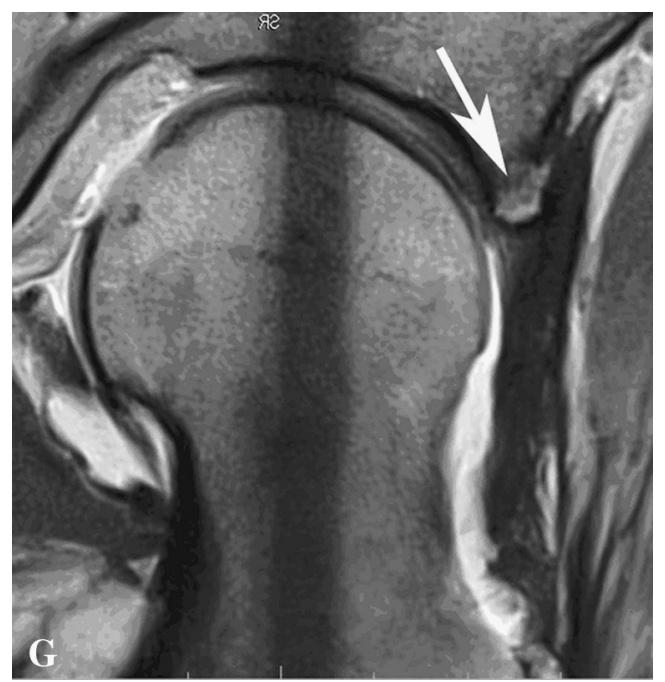

Fig. 1A-G continued

defect); B, regrowth of a new structure; and C, replacement with tissue confluent with the overlying capsule (Fig. 1). In the circumstance of new tissue formation (B or $\mathrm{C}$ ), the tissue was further classified as: 1, dense fibrous tissue equivalent to normal labrum; 2, low-density scar, synovium, or cyst; or 3, bone, and the amount of tissue regrowth was designated as complete or incomplete. Therefore, credible regeneration of a structure bearing the location and density of the labrum was classified as B1 or C1 and incomplete if it did not approximate the normal labrum in volume.

Disagreements among the four observers occurred in the categorization of soft tissue density. In five areas, one of the four observers (the same in all cases) classified areas of new tissue as high density, which all others classified as low density. These disagreements were resolved by consensus after reevaluation of the MRA images.

\section{Outcome Assessment}

During the period of the study, no preoperative scores were routinely assessed. Information regarding hip motion, complications, conversion to joint replacement, and any reoperation was gathered from patient preoperative records and at followup examination.

\section{Statistics}

Given the small number of patients, only mean values and SDs were calculated.

\section{Results}

\section{Labral Regrowth}

In six hips, segmental defects with no tissue regrowth (tissue response A) were identified. Low-density scar replaced some of the resected labrum in seven hips, and such areas were observed in all three cases without segmental defects. Bone had grown into the areas of labral excision in five hips. The bone was covered with a thin layer or tuft of soft tissue (Fig. 2). New bone formation was most frequently located along the superior margin of the acetabulum. In six hips the capsule was focally or extensively confluent with new tissue formed in the area of the labral resection, creating a single structure (Fig. 1E). This structure was heterogeneous and included bone, dense tissue, and, in one instance, a cyst.

In no hip was the void left by excision fully replaced by tissue that-by contour, position, or density — could be interpreted as a regenerated labrum. Focal areas where dense fibrous tissue resembling normal labrum had reformed were identified by one or more reviewers in three subjects. After discussion, observer consensus was that a structure similar in density to normal labrum (B1) reformed in only one subject. The structure was incomplete; the questionable new formation was torn and voids were observed in other areas of the hip.

Adhesions between the capsule and the area of femoral osteoplasty were found in six of the nine cases. These were all limited to the distal half of the osteoplasty site adjacent to the capsular insertion (Fig. 1B). The condition of the pericapsular muscles (iliocapsularis and gluteus minimus) was good in all cases with minimal degeneration and no heterotopic bone apparent. The femoral osteoplasty showed 


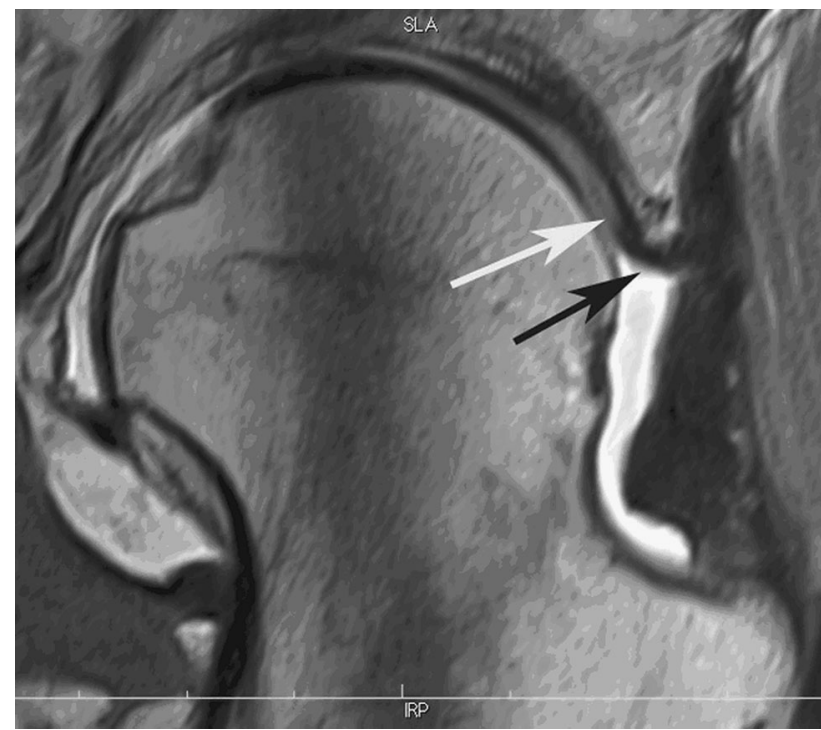

Fig. 2 Here the void has been partially filled with new bone (white arrow), which is covered by a layer of dense fibrous tissue (black arrow) that could appear to be normal labral edge by arthroscopy.

no signs of filling in with new bone or other change in contour. In all cases, a thin smooth cortex, approximately $1 \mathrm{~mm}$ in thickness, covered the femoral osteoplasty site, but this cortex was somewhat thinner and irregular where capsular adhesions were present.

\section{Demographics and Clinical Outcomes}

No intraoperative or postoperative complications occurred. The trochanteric screws were removed in seven patients. At the time of followup, none of the hips had to be converted to or was scheduled for a THA and no patient had requested further surgical treatment of the hip in question. The mean Harris hip score was $83 \pm 14$ and the UCLA score $6 \pm 2$.

\section{Discussion}

\section{Background, Rationale, and Study Findings}

Approximately $90 \%$ of patients with FAI are found to have labral disruption at surgery [14, 16, 40, 45]. In surgical management of these injuries, one may repair, excise, or replace an unstable segment. A surgeon also has the option of repair, reconstruction, or resection when the labrum is detached for rim resection. Several clinical studies suggest that patients with repairs fare better than those with excision $[20,22,31,35-37,51]$, but another study found that the labrum is repaired in only one-fourth of arthroscopic and $45 \%$ of open FAI cases [12]. As a result of extent, location, and available tissue, some tears can be difficult to repair. Proponents of débridement argue that repair cannot restore normal biomechanical function of the labrum [59]. Bony deformities, specifically acetabular dysplasia and those causing FAI, are common in patients with labral injuries [41, 57], and failure to correct these deformities has been linked to worse outcomes [7, 17, 29, 32, 38, 42, $46,47]$. Therefore, some reviews imply that it may be possible to obtain comparably good results with simple débridement in subjects without FAI, arthrosis, or dysplasia [28]. Another explanation for good results with débridement would be spontaneous regeneration of functional labral tissue. In this MRA study of nine patients, however, we found little evidence of labral regeneration 3 to 7 years after segmental resection of the acetabular labrum. Usually, any new growth was low-density scar (found in seven cases) or new bone (found in five cases). Voids with no regrowth were present in six hips, and one patient exhibited no regrowth at all. Adhesions between the capsule and the new tissue were also common.

\section{Limitations}

This study had several limitations. Our sample number was small and five patients (out of 14) were lost at followup, nevertheless we believe it represents a reasonable proportion of our patients treated by excision to bone, because this was very rare in our clinical practice. The débridement technique was uniform, and bony impingement was corrected by a single, experienced surgeon with highly standardized surgery and patient care.

It is possible that patients with an exceptionally good or bad result may have had a bias about followup when recruited for the study but none of them were seeking additional evaluation or treatment. At the time of the study, no preoperative scores were routinely assessed; thus, it is possible that these patients did not improve or that improvement was not sustained. The observed results might be different in patients not willing to come because the absence of evidence of regrowth in the nine patients is not an absolute evidence of no regeneration potential. Indeed, Abrams et al. [1] found arthroscopic evidence of labral regeneration in asymptomatic patients. Nevertheless, if we speculate and consider dropouts as having bad outcomes, it seems even more unlikely that resection should be considered as a viable alternative to reconstruction.

MRA cannot detect all abnormalities in the hip, particularly after previous surgery [3,4], and in that regard is not equivalent to arthroscopic or direct examination. The major limitation in the diagnosis of labral pathology by MRA is false-negatives [3, 39, 49]. Because positive predictive 
value of MRA is good, the central finding in this study-a high incidence of abnormalities-should be valid. In reading the radial reconstructions, our challenge was discrimination among cysts, voids, and low-density scar, thus needing a consensus, but not in the recognition of a reconstituted equivalent to the acetabular labrum: the lack of regeneration was clear for all authors. In many cases, the capsule was directly apposed to the tissues formed in the site of excision, and we were unable to determine if the two were fused. This did not affect our central findings. All patients were treated with ibuprofen for a short time after surgery; this could affect soft tissue repair, but ibuprofen may have minimal effects in this regard when compared with other nonsteroidal antiinflammatory agents [25]. Nothing else in the recovery protocol should interfere with healing or promote bone formation on the rim.

\section{Discussion of Imaging}

In contrast to our sheep model, excision of an irreparable labrum down to bone does not lead to formation of a "neolabrum" [43]. MRA does provide a cross-section of the labrum, and in our study, we could see that new tissue formed in the site of resection was largely bone, lowdensity scar, or cyst. On arthroscopic evaluation, these areas may appear to be reconstituted labrum, especially when fibrous tissue covered these abnormal formations (Fig. 2). MRA revealed frank defects, areas of scarring to the capsule, and areas where the new tissue was not apposed to the femoral head. The normal function of the acetabular labrum is subject to debate, but the defects observed in our hips would compromise the ability to provide a seal or to act as a circumferential ring to absorb hoop stresses. For these reasons, we conclude that excision to bone does not stimulate regrowth of a functional labrum. Areas of new bone formation might extend the weightbearing area but also have the potential to impinge. The tissue response was consistently inadequate. Compared with the entire group of patients having open treatment for FAI at our institution, these subjects were slightly older (34 versus 30 years). Abrams et al. [1] found a positive relationship between age and the presence of "inhomogeneous regrowth" of the labrum, and the average age of their subjects was 29 years. The condition of the labrum after various hip preservation procedures has been examined by arthroscopy [1, 18, 29, 34, 53], MRA [3, 5, 11, 18], and during open procedures [6, 38]. Overall, these reports contain only limited information on the extent of the initial labral resection. In most series, reevaluation was performed because the patients were symptomatic. In an MRA study of symptomatic hips, Blankenbaker et al. [11] noted a reduced volume of labrum in all areas of previous partial resection. May et al. [38] show a photograph of such a truncated labral remnant observed during surgical dislocation. Conversely, Abrams et al. [1] found arthroscopic evidence of labral regeneration in 24 asymptomatic patients 2 years after open resection. In 21 of those 24 , the new tissue resembled the native labrum in size with 6 to $8 \mathrm{~mm}$ of "regrowth," which is comparable to the normal width of the labrum [54].

\section{Discussion of Outcomes}

Validated outcomes scores for this small group varied and overall were slightly lower than the midterm values reported for patients with FAI from the same institution [45]. It is however no surprise that this group had somewhat lower scores. According to more recent studies, subjects with labral excision have lower scores at around two years than those with repairs [22, 37]. Scarring between the capsule and the labrum-as observed here by the MRAs - has been found after acetabular osteotomy and both open and arthroscopic FAI surgery [1, 18, 34, 53]. Beck [9] proposed that adhesions might interfere with the labral sealing mechanism and in fact advocated their débridement. This form of scar was common in our group but could not be correlated with individual outcome values because of sample size. The patient with worst pain score in fact had minimal scar formation. It is possible that arthroscopy overestimates the extent of functional labral regeneration in areas where bone or incompetent connective tissue is obscured by a layer of capsule.

\section{Conclusions}

Because we performed a resection to bone, it is difficult to compare our results with other studies where the amount of resection is unspecified $[1,3,5,6,11,18,29,34,38,53]$ and was probably limited to partial débridement in many cases. We attempt to repair most labral tears, but the patients here had no option other than reconstruction with a graft, a procedure we had not adopted at the time. We had theorized that exposure of bone would, as apparently occurred in the sheep model [43], stimulate new tissue formation. Unfortunately, much of the regrowth was bone identical to osteophyte. When a simple refixation is not possible, we now typically use the ligamentum teres to augment a very thin or reconstruct a missing labrum. In contrast to our sheep model, excision of an irreparable labrum down to bone does not lead to formation of a "neolabrum." Correlation of this anatomic observation with patient function and satisfaction would require a larger study. These results cannot be extended to situations in 
which the labrum is trimmed but not excised. Future studies of labral débridement would be improved by more precise quantification and definition of "excision" and "débridement."

\section{References}

1. Abrams GD, Safran MR, Sadri H. Spontaneous hip labrum regrowth after initial surgical débridement. Clin Orthop Relat Res. 2013;471:2504-2508.

2. Altenberg AR. Acetabular labrum tears: a cause of hip pain and degenerative arthritis. South Med J. 1977;70:174-175

3. Aprato A, Jayasekera N, Villar RN. The accuracy of magnetic resonance arthrography in hip arthroscopic labral revision surgery. Hip Int. 2013;23:99-103.

4. Aprato A, Jayasekera N, Villar RN. Revision hip arthroscopic surgery: outcome at three years. Knee Surg Sports Traumatol Arthrosc. 2014;22:932-937.

5. Aprato A, Masse A, Faletti C, Valente A, Atzori F, Stratta M, Jayasekera N. Magnetic resonance arthrography for femoroacetabular impingement surgery: is it reliable? J Orthop Traumatol. 2013;14:201-206.

6. Audenaert EA, Dhollander AA, Forsyth RG, Corten K, Verbruggen G, Pattyn C. Histologic Assessment of acetabular labrum healing. Arthroscopy. 2012;38:1784-1789.

7. Bardakos NV, Vasconcelos JC, Villar RN. Early outcome of hip arthroscopy for femoroacetabular impingement: the role of femoral osteoplasty in symptomatic improvement. J Bone Joint Surg Br. 2008;90:1570-1575.

8. Bastian JD, Wolf AT, Wyss TF, Notzli HP. Stepped osteotomy of the trochanter for stable, anatomic refixation. Clin Orthop Relat Res. 2009;467:732-738.

9. Beck M. Groin pain after open FAI surgery: the role of intraarticular adhesions. Clin Orthop Relat Res. 2009;467:769-774.

10. Beck M, Fucentese SF, Staub L, Siebenrock K. [Surgical dislocation of the hip for the treatment of femoroacetabular impingement. Technique and results] [in German]. Orthopade. 2009;38:412-418.

11. Blankenbaker DG, De Smet AA, Keene JS. MR arthrographic appearance of the postoperative acetabular labrum in patients with suspected recurrent labral tears. AJR Am J Roentgenol. 2011;197:W1118-1122.

12. Botser IB, Smith TW Jr, Nasser R, Domb BG. Open surgical dislocation versus arthroscopy for femoroacetabular impingement: a comparison of clinical outcomes. Arthroscopy. 2011;27: 270-278.

13. Byrd JW, Jones KS. Hip arthroscopy for labral pathology: prospective analysis with 10-year follow-up. Arthroscopy. 2009;25: 365-368.

14. Byrd JW, Jones KS. Arthroscopic management of femoroacetabular impingement: minimum 2-year follow-up. Arthroscopy. 2011;27:1379-1388.

15. Cadet ER, Chan AK, Vorys GC, Gardner T, Yin B. Investigation of the preservation of the fluid seal effect in the repaired, partially resected, and reconstructed acetabular labrum in a cadaveric hip model. Am J Sports Med. 2012;40:2218-2223.

16. Clohisy JC, Baca G, Beaule PE, Kim YJ, Larson CM, Millis MB, Podeszwa DA, Schoenecker PL, Sierra RJ, Sink EL, Sucato DJ, Trousdale RT, Zaltz I. Descriptive epidemiology of femoroacetabular impingement: a North American cohort of patients undergoing surgery. Am J Sports Med. 2013;41:1348-1356.
17. Clohisy JC, Nepple JJ, Larson CM, Zaltz I, Millis M. Persistent structural disease is the most common cause of repeat hip preservation surgery. Clin Orthop Relat Res. 2014;471:3788-3794.

18. Dudda M, Mamisch TC, Krueger A, Werlen S, Siebenrock KA, Beck M. Hip arthroscopy after surgical hip dislocation: is predictive imaging possible? Arthroscopy. 2011;27:486-492.

19. Dy CJ, Thompson MT, Crawford MJ, Alexander JW, McCarthy JC, Noble PC. Tensile strain in the anterior part of the acetabular labrum during provocative maneuvering of the normal hip. $J$ Bone Joint Surg Am. 2008;90:1464-1472.

20. Ejnisman L, Philippon MJ, Lertwanich P. Acetabular labral tears: diagnosis, repair, and a method for labral reconstruction. Clin Sports Med. 2011;30:317-329.

21. Espinosa N, Beck M, Rothenfluh DA, Ganz R, Leunig M. Treatment of femoro-acetabular impingement: preliminary results of labral refixation. Surgical technique. J Bone Joint Surg Am. 2007;89(Suppl 2):36-53.

22. Espinosa N, Rothenfluh DA, Beck M, Ganz R, Leunig M. Treatment of femoro-acetabular impingement: preliminary results of labral refixation. J Bone Joint Surg Am. 2006;88:925-935.

23. Ferguson SJ. The influence of the acetabular labrum on hip joint cartilage consolidaction: a poroelastic finite element model. $J$ Biomech. 2000;33:953-960.

24. Ferguson SJ, Bryant JT, Ganz R, Ito K. An in vitro investigation of the acetabular labral seal in hip joint mechanics. J Biomech. 2003;36:171-178.

25. Ferry ST, Dahners LE, Afshari HM, Weinhold PS. The effects of common anti-inflammatory drugs on the healing rat patellar tendon. Am J Sports Med. 2007;35:1326-1333.

26. Geyer MR, Philippon MJ, Fagrelius TS, Briggs KK. Acetabular labral reconstruction with an iliotibial band autograft: outcome and survivorship analysis at minimum 3-year follow-up. Am J Sports Med. 2013;41:1750-1756.

27. Greaves LL, Gilbart MK, Yung AC, Kozlowski P, Wilson DR. Effect of acetabular labral tears, repair and resection on hip cartilage strain: a 7T MR study. J Biomech. 2010;43:858-863.

28. Haviv B, O'Donnell J. Arthroscopic treatment for acetabular labral tears of the hip without bony dysmorphism. Am J Sports Med. 2011;39(Suppl):79S-84S.

29. Heyworth BE, Shindle MK, Voos JE, Rudzki JR, Kelly BT. Radiologic and intraoperative findings in revision hip arthroscopy. Arthroscopy. 2007;23:1295-1302.

30. Hlavacek M. The influence of the acetabular labrum seal, intact articualr superficial zone and synovial fluid thixotropy on squeeze-film lubrication of a spherical synovial joint. $J$ Biomech. 2002;35:1325-1335.

31. Kalore NV, Jiranek WA. Save the torn labrum in hips with borderline acetabular coverage. Clin Orthop Relat Res. 2012;470: 3406-3413.

32. Kemp JL, Collins NJ, Makdissi M, Schache AG, Machotka Z, Crossley K. Hip arthroscopy for intra-articular pathology: a systematic review of outcomes with and without femoral osteoplasty. Br J Sports Med. 2012;46:632-643.

33. Konrath GA, Hamel AJ, Olson SA, Bay B, Sharkey NA. The role of the acetabular labrum and the transverse acetabular ligament in load transmission in the hip. J Bone Joint Surg Am. 1998; 80:1781-1788.

34. Krueger A, Leunig M, Siebenrock KA, Beck M. Hip arthroscopy after previous surgical hip dislocation for femoroacetabular impingement. Arthroscopy. 2007;23:1285-1289.e1281.

35. Krych AJ, Thompson M, Knutson Z, Scoon J, Coleman SH. Arthroscopic labral repair versus selective labral débridement in female patients with femoroacetabular impingement: a prospective randomized study. Arthroscopy. 2013;29:46-53. 
36. Larson CM, Giveans MR. Arthroscopic débridement versus refixation of the acetabular labrum associated with femoroacetabular impingement. Arthroscopy. 2009;25:369-376.

37. Larson CM, Giveans MR, Stone RM. Arthroscopic débridement versus refixation of the acetabular labrum associated with femoroacetabular impingement: mean 3.5-year follow-up. Am J Sports Med. 2012;40:1015-1021.

38. May O, Matar WY, Beaule PE. Treatment of failed arthroscopic acetabular labral débridement by femoral chondro-osteoplasty: a case series of five patients. J Bone Joint Surg Br. 2007;89:595598.

39. McCarthy JC, Glassner PJ. Correlation of magnetic resonance arthrography with revision hip arthroscopy. Clin Orthop Relat Res. 2013;471:4006-4011.

40. McCarthy JC, Jarrett BT, Ojeifo O, Lee JA, Bragdon CR. What factors influence long-term survivorship after hip arthroscopy? Clin Orthop Relat Res. 2011;469:362-371.

41. Meermans G, Konan S, Haddad FS, Witt JD. Prevalence of acetabular cartilage lesions and labral tears in femoroacetabular impingement. Acta Orthop Belg. 2010;76:181-188.

42. Meftah M, Rodriguez JA, Panagopoulos G, Alexiades MM. Long-term results of arthroscopic labral débridement: predictors of outcomes. Orthopedics. 2011;34:e588-592.

43. Miozzari HH, Clark JM, Jacob HA, von Rechenberg B, Notzli HP. Effects of removal of the acetabular labrum in a sheep hip model. Osteoarthritis Cartilage. 2004;12:419-430.

44. Myers CA, Register BC, Lertwanich P, Ejnisman L, Pennington WW, Giphart JE, LaPrade RF, Philippon MJ. Role of the acetabular labrum and the iliofemoral ligament in hip stability: an in vitro biplane fluoroscopy study. Am J Sports Med. 2011; 39(Suppl):85S-91S.

45. Naal FD, Miozzari HH, Schar M, Hesper T, Notzli HP. Midterm results of surgical hip dislocation for the treatment of femoroacetabular impingement. Am J Sports Med. 2012;40:1501-1510.

46. Nepple JJ, Zebala LP, Clohisy JC. Labral disease associated with femoroacetabular impingement: do we need to correct the structural deformity? J Arthroplasty. 2009;24:114-119.

47. Parvizi J, Bican O, Bender B, Mortazavi SM, Purtill JJ, Erickson J, Peters C. Arthroscopy for labral tears in patients with developmental dysplasia of the hip: a cautionary note. J Arthroplasty. 2009;24:110-113.
48. Philippon MJ, Arnoczky SP, Torrie A. Arthroscopic repair of the acetabular labrum: a histologic assessment of healing in an ovine model. Arthroscopy. 2007;23:376-380.

49. Philippon MJ, Schenker ML, Briggs KK, Kuppersmith DA, Maxwell RB, Stubbs AJ. Revision hip arthroscopy. Am J Sports Med. 2007;35:1918-1921.

50. Robertson WJ, Kadrmas WR, Kelly BT. Arthroscopic management of labral tears in the hip: a systematic review of the literature. Clin Orthop Relat Res. 2007;455:88-92.

51. Schilders E, Dimitrakopoulou A, Bismil Q, Marchant P, Cooke C. Arthroscopic treatment of labral tears in femoroacetabular impingement: a comparative study of refixation and resection with a minimum two-year follow-up. J Bone Joint Surg Br. 2011;93:1027-1032.

52. Sierra RJ, Trousdale RT. Labral reconstruction using the ligamentum teres capitis: report of a new technique. Clin Orthop Relat Res. 2009;467:753-759.

53. Suzuki C, Harada Y, Mitsuhashi S, Yamashita K, Watanabe H, Tsuchiya A, Moriya H. Repair of cartilage defects and torn acetabular labrum in hip joints after conventional osteotomy: evaluation by follow-up arthroscopy. J Orthop Sci. 2005;10:127132.

54. Tan V, Seldes RM, Katz MA, Freedhand AM, Klimkiewicz JJ, Fitzgerald RH Jr. Contribution of acetabular labrum to articulating surface area and femoral head coverage in adult hip joints: an anatomic study in cadavera. Am J Orthop (Belle Mead NJ). 2001;30:809-812.

55. Tey M, Erquicia JI, Pelfort X, Miquel J, Gelber PE, Ribas M. Allogenic labral transplantation in hip instability following arthroscopic labrectomy. Hip Int. 2011;21:260-262.

56. Weigel DP, Callaghan JJ. Use of anchor sutures to repair labral avulsions of the hip: a brief report. Iowa Orthop J. 1997;17:141143.

57. Wenger DE, Kendell KR, Miner MR, Trousdale RT. Acetabular labral tears rarely occur in the absence of bony abnormalities. Clin Orthop Relat Res. 2004;426:145-150.

58. Zahiri CA, Schmalzried TP, Szuszczewicz ES, Amstutz HC. Assessing activity in joint replacement patients. J Arthroplasty. 1998;13:890-895.

59. Zaltz I. The biomechanical case for labral débridement. Clin Orthop Relat Res. 2012;470:3398-3405. 